\title{
El Muro de Berlín y la cuestión alemana: reflexiones de un caminante
}

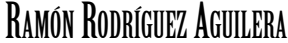 \\ Facultad de Filosofía \\ Universidad de Sevilla y Freie Universität Berlin
}

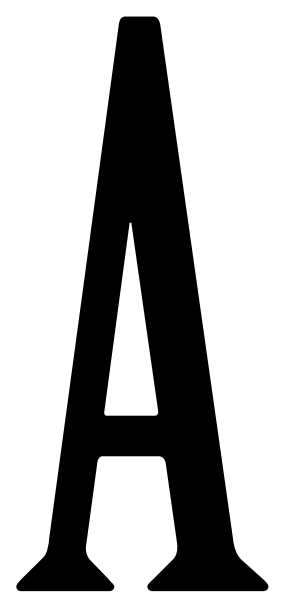

comienzos de los ochenta comencé a pasar parte de mis vacaciones de verano en Berlín. Decir con más precisión «Berlín Occidental» me parece ahora innecesario, pues aquella ciudad, ocupada por los vencedores de Segunda Guerra Mundial y dividida después en dos partes incomunicadas por una frontera interior, seguía siendo en alguna forma no del todo explicable una unidad viva y atractiva, una célula única en el mapa de la geografía mental y orgánica del mundo, capaz de resistir la destrucción, el aislamiento y la veleidad. Su solo nombre perdurable y unido a aquel espacio concreto parecía poder digerir, con infatigable imaginación, la razón y la sinrazón de la intromisión humana.

Entre julio y agosto me inscribía durante un mes en alguna academia de idiomas, en realidad, de alemán para extranjeros, estudiantes en su mayoría. Y me hospedaba en casa de un amigo, con el que había cursado en los años setenta historia moderna en la Universidad Central de Barcelona. Por una razón que se aclarará más tarde su casa se encontraba siempre muy cerca del Muro: en Leutschnerdamm, junto a Oranienplatz (Kreuzberg), primero, y más tarde (en 1987) no muy lejos del control de ChekpointCharlie, en Lindens trasse 37.

En aquella «isla política», un enclave del mundo occidental adentrado en el espacio político comunista, parecía como si se hubiese asentado lo mejor del heterogéneo y polémico espíritu del 68; sin duda, allí se había recogido, sosegada, la agitada ola de contestación social confundiéndose con sus peculiares formas de vida. Así parecían recordarlo los nombres de algunos de los líderes del 68, impresos ya en su toponimia, y el nuevo partido político alemán Los Verdes (fundado en 1980) con sus nuevos presupuestos ecologistas, antinucleares y pacifistas, que tan bien encajaban con el aire social de la ciudad. Berlín Occidental era un ejemplo de la recuperación cívica de Alemania después de haber firmado, deshecha, su capitulación incondicional al final de la Segunda Guerra Mundial. Aquella sociedad berlinesa había vencido definitivamente la violencia criminal nazi y había resuelto de manera realista la secular tensión alemana moderna entre «militarismo y pacifismo», abriéndose a la vida internacional sin pulsión imperialista alguna y dejando paso a una competitividad cooperativa y a una apetencia por la vida sana y tranquila. Con un estatus político especial, que excluía el servicio militar obligatorio (lo que era un motivo de atracción particular para algunos jóvenes varones de Alemania occidental), aquella ciudad (o medio ciudad) vivía, sin trauma alguno, una vida relajada, confortable y animada, donde la palabra "guerra» diríase sustituida definitivamente por la palabra «seguridad».

Pero, como consecuencia de la devastadora derrota y sobre todo de su aislamiento físico posterior, Berlín Occidental sólo indirectamente se había beneficiado del boom económico anterior de Alemania occidental (1950-1973) y carecía de un tejido industrial productivo importante; ni producía coches ni tenía grandes autopistas, sino que dependía principalmente de los servicios y de la actividad cultural. En este sentido, era una ciudad europea atípica: con una escasa producción económica y sin una clase obrera en sentido moderno. En compensación, desde los primeros momentos de la postguerra, abastecida entonces por un puente aéreo, se había desarrollado como una meta «intelectual» para muchos artistas y escritores alemanes y extranjeros, que parecían encontrarse allí, por así expresarlo, en los límites del centro del mundo. Berlín Occidental era, en efecto, un lugar recluido que permitía al mismo tiempo evocar con sosiego el pasado y mirar con imaginación hacia el futuro. Una cierta austeridad en el vestir seguía recordando de manera indirecta la impronta más proletaria del pasado, en cierto contraste, por ejemplo, con la elegante suavidad de Munich, o incluso con el carácter burgués de Hamburgo.

El Muro, la frontera que separaba el «Berlín Oriental» del «Berlín Occidental» en línea continua con la división política de Alemania, a pesar de datar sólo de algo más de dos décadas, parecía ser, en su modesta altura y extensión gris, un accidente geofísico, sólido, calloso, inamovible. Cruzaba por el que había sido el centro más deslumbrante de la ciudad metropolitana de los años treinta, Potsdamer Platz, un lugar emblemático realmente irreconocible por la destrucción de la Guerra y por la ocupación militar posterior. Precisamente allí se delimitaban mutuamente, el sector soviético, por el este, y el sector norteamericano (y británico), por el oeste, sobre una superficie ahuecada y vacía. Al deambular por la ciudad te lo topabas siempre, pues el Muro cortaba de manera implacable calles, plazas, metro, y puentes, impidiendo el transporte y la movilidad entre ambos lados de la ciudad dividida, y sobre todo obligando a un tránsito minuciosamente vigilado por la autoridad militar comunista. En la imaginación de la época esta barrera y este control significaban, además, «espionaje» y «contraespionaje», o incluso intercambio político pactado. La sufrida interrupción de relaciones humanas entre ambos lados de la ciudad había quedado relegada al silencio de la vida privada y local, y no era un tema de conversación, al menos para el turista.

En el lado occidental, se había conformado, de manera adaptativa, una orientación nueva, y hasta una circulación paralela y pegada al Muro mismo, a pié o en bicicleta. Desde el lado orien- 
En el lado occidental, se había conformado, de manera adaptativa, una orien-

tación nueva, y hasta una circulación paralela y pegada al Muro mismo, a

pié o en bicicleta. Desde el lado oriental, sin embargo, el Muro se hallaba

separado por una segunda barrera alambrada, con un espacio interpuesto,

inerte, e intransitable para el ciudadano.

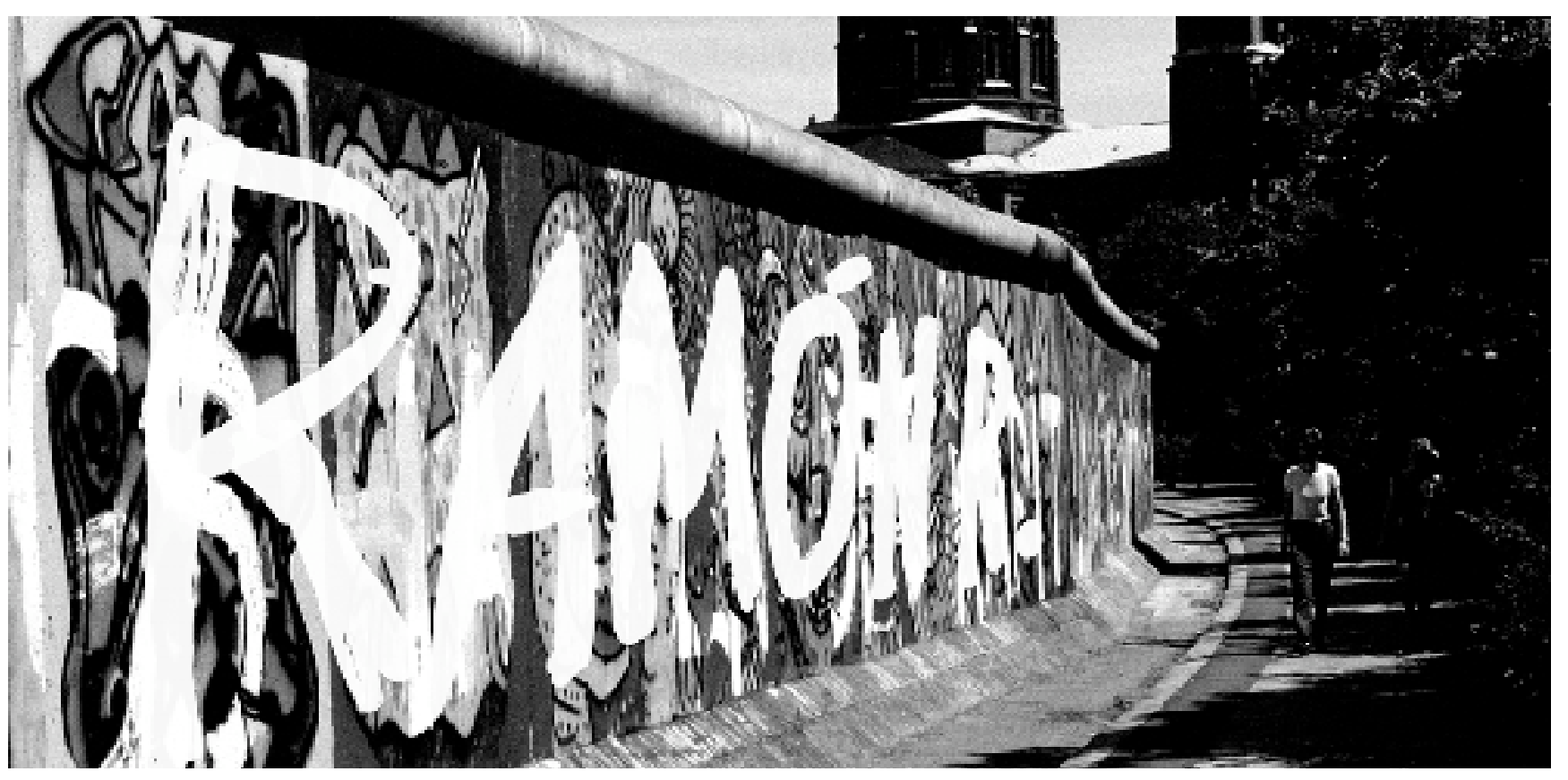

tal, sin embargo, el Muro se hallaba separado por una segunda barrera alambrada, con un espacio interpuesto, inerte, e intransitable para el ciudadano. Las torres de vigilancia y la guardia de la frontera emitían un chirrido áspero y discordante con el cuerpo a pesar de todo flexible de la ciudad. No podían menos que seguir evocando la Guerra. Y cuando avistabas desde la altura aquel paisaje disecado, y reconocías sus señales y sus huellas, se te prendían a los ojos imágenes fantasmas asociadas a los campos de concentración y al trabajo forzado. En un rótulo que ha dejado huella quedaba claro: una defensa bélica de la "paz».

Desde un punto de vista urbanístico, el Muro sustraía además para el lado oriental, el núcleo histórico más valioso y emblemático de la ciudad prusiana: comenzando por la puerta de Branderburgo (que entonces daba, por así decirlo, dos veces la espalda a Occidente), siguiendo por la avenida Unter den Linden, e incluyendo, por ejemplo, la serena y hermosa plaza de la Gendarmenmarkt, con la estatua de Schiller delante de la Casa del Teatro entre la Catedral Alemana y la Catedral Francesa hugonote. Y, en general, en sector oriental contenía la gran arquitectura de K. F. Schinkel (1781-1841) y de sus discípulos, que, desde el Siglo XIX hasta 1930 (en que se construyó el Museo Pergamon), habían hecho de Berlín una ciudad política moderna sin apenas dependencia medieval, sólida y coherente. La deslumbrante solidez arquitectónica del Siglo XIX mantenía, en efecto, en aquel lado, su expresión más continua.
En la parte occidental, tan menguada tras el reparto, se había conformado un centro simbólico, comunicativo y comercial en torno a la avenida de la Kurfürstendamm y la Gedachtnisskirche, la Iglesia de la que quedaba en pié la «Torre rota», frente al icono más alto, móvil y lunar, de Mercedez Benz. Esta parte de la ciudad era estilísticamente muy inferior a todo el núcleo de piedra neoclásica del lado oriental, pero bullía en ella la vida y estaba muy bien conectada, internamente y hasta el nuevo aeropuerto de Tegel, en el norte, que pertenecía al sector francés. El visitante quedaba muy pronto atrapado en la vida de la ciudad (en sus cafeterías y en sus parques) y no parecía en absoluto sentirse constreñido por el cerco que la rodeaba, ni echar tampoco nada en falta. Berlín no sólo resultaba ya inconcebible sin el Muro, sino que el Muro mismo era un motivo central de interés en la visita. ¿Por qué?

El Muro despertaba siempre un interés porque era parte y símbolo de la omnipresente e inapelable Guerra Fría: el icono más expresivo del status quo del mundo de la postguerra. Su percepción comprensiva te ponía en contacto con realidades y pensamientos que lo trascendían como cosa física, y que, incluso, lo precedían en el tiempo. Desde 1946 el «telón de acero» había dejado de ser una mera metáfora teatral retórica; era una realidad política y cultural definitoria del nuevo periodo histórico: la vertebra física central de la tensión bipolar, militar y humana, que articulaba las relaciones internacionales de postguerra. Continuas 
y dificultosas habían sido las migraciones políticas desde el mundo comunista, y en particular, desde todos los países del Este de Europa, hacia todo el mundo occidental. Y, precisamente, éste era el principal objetivo del levantamiento, imprevisto y rápido, de aquella barrera de cemento berlinesa: contener el potencial flujo migratorio de refugiados, impedir la fuga continua de los desafectos a las formas de vida impuestas por el régimen comunista, que podían encontrar mejores expectativas de vida en occidente, y que ya venían arriesgándose a ello bajo controles menos seguros. Muy pronto se había constatado en la ciudad de postguerra que no era viable una administración conjunta de los cuatro poderes ocupantes, y, sobre todo, por parte del «Berlín soviético», que tampoco era posible una separación de las dos economías con sus respectivas monedas en circulación. Lejos, pues, de ser un mero estorbo, el Muro había adquirido relativamente pronto función y rango de necesidad (social, política, histórica). Por aquellos años, los dos Estados alemanes, sin dejar de estar pendiente el uno del otro, parecían haber renunciado ya a los contragolpes anteriores de efecto propagandístico, y el Muro separaba y delimitaba, pues, dos universos políticos, que parecían abarcarlo todo: enfrentados y competidores, pero bien asentados, incuestionables e irreductibles.

\section{El Muro de las pasiones}

El Muro había generado, y seguía generando emociones y pasiones sociales en todo el mundo, y no sólo en Alemania o en Europa. A nadie le resultaba indiferente, pues allí estaba en juego algo que no parecía concluido.

El entero mundo comunista, y no sólo el nuevo estado de la República Democrática Alemana (RDA), controlado desde sus inicios por la Unión Soviética, al ejercer esta forma de «autodefensa» proteccionista y represiva, ponía de manifiesto, en primer lugar, las limitaciones de su apoyo humano interior y dejaba además claramente en entredicho su proclamado universalismo liberador. El futuro ideal del socialismo internacional comenzaba en el presente real de una economía y una sociedad en manos del Estado. Socialismo-comunismo, en su significación más espontánea, quería decir más igualdad y homogeneidad social, es decir, menores diferencias materiales y culturales entre las distintas categorías socio-laborales de la sociedad. Mucha gente asumía esta idea como una verdad obvia. Pero el poder y el proyecto comunista eran también visiblemente un dique armado de contención de la economía comercial del capitalismo y de la democracia, que ya habían resonado con fuerza a comienzos del siglo XX. El Muro venía a clavarse como una pieza central en este esquema comprensivo de la historia del presente.

El mundo occidental, por su parte, y bajo la hegemonía de Estados Unidos, al soportar aquel roce directo de la amenaza militar mutua, cohabitando incluso en la misma ciudad con el enemigo, sacaba en principio ventaja en la guerra de las ideas frente a la proclamada superioridad de la «democracia socialista». Legalmente Berlín Occidental no pertenecía a la República Federal de Alemania, pero formaba parte de su sociedad y de su economía, y bajo el control de los ocupantes occidentales se permitían, como en toda la Alemania Occidental, elecciones libres; en su caso, sólo a la alcaldía. Aquel pequeño y cercado mundo humano se hallaba, pues, bien integrado en los intereses y en los va- lores de la Comunidad Internacional Occidental.

«Berlín Oriental», tal y como decíamos en occidente, o «Berlín capital de la República Democrática Alemana», tal y como se hacía llamar enérgicamente por el nuevo estado comunista, vista desde fuera, parecía, sin embargo, algo encastillada en sí misma. Y distante: de alguna forma, distante de sí misma. Aquella parte notable de la ciudad pretendía ser para el «Segundo Estado Alemán Soberano» (ésa era su denominación constitucional de 1968) un «escenario para el mundo». Y se hallaba, ciertamente, conectada y abierta al mundo, sobre todo, por medios diplomáticos, y se realizaba en ella un constante esfuerzo de renovación y de mejora, y hasta de festiva celebración histórica: con toda la seriedad y el empeño posible. Pero, los brazos se quedaban, por así decirlo, arqueados en el aire antes de abrazar su cuerpo físico del visitante: resulta difícil de explicar esta sensación de desencuentro personal con el entorno, de falta de tacto y contacto.

El mundo político occidental se veía, a su vez, forzado a inventar de maneras diversas el rostro humano del «otro», a pesar de la proximidad urbana, pertrechado y oculto. Fuera de Alemania, los partidos comunistas, cada vez más debilitados en la estela del proclamado post-estalinismo, exaltaban todavía, desde lejos, algunos logros materiales y sociales del «socialismo real». Muchos líderes del Tercer Mundo habían asociado con fervor durante años el ideal de justicia social con el comunismo. Y los defensores de la de la democracia liberal "occidental», se venían plegando desde hacía tiempo a los presupuestos del relativismo cultural, al reconocer que en la práctica, los derechos humanos y sociales, sustentados acaso en valores morales universales, de hecho dependían del contexto socio-cultural. Los acuerdos de Helsinki de 1975 habían arrancado de la Unión Soviética un cierto reconocimiento público de los derechos humanos, y que con ello comenzaba a animarse a la oposición política en todo el bloque satélite del Este europeo. Pero nada de esto parecía notarse, sin embargo, en la RDA: el país más preciado y estratégico, más desarrollado y «mimado» por la Unión Soviética de la órbita europea socialista. ¿Por qué? Parecía como si allí no se hubieran olvidado ciertas lecciones recientes: donde habían ido a parar la discrepancias con el poder en todos los «estados hermanos» en 1953, 1956, 1968, 1977, 1980.

La permanencia del Muro llevaba consigo, pues, un estado de hechos y de actitudes con los que había que vivir, a un lado y al otro, de cerca y de lejos.

No lo sostenían, desde el principio, manos alemanas sino equilibrios internacionales, y en última instancia, el poder de la Unión Soviética, una poderosa e imperial maquinaria militar que por alguna razón quería mejorar las relaciones con occidente, sin aspirar ya a extender mundialmente la revolución internacional de sus orígenes fundacionales. Pero, con su internacionalismo doctrinario seguía de hecho bloqueando los mecanismos del mercado, interna y externamente, y repeliendo el espíritu cosmopolita y tolerante. Pero ocultaba bien su estancamiento y no parecía todavía ni resquebrajada ni debilitada. Al menos así se percibía desde Berlín.

Se ha comentado con frecuencia que la competencia ideológica asociada a la confrontación bipolar favoreció a largo plazo la introducción en la democracia capitalista de formas de justicia política distributiva, reivindicadas también, obviamente, desde 
dentro. Este efecto competitivo no sólo era cierto sino también recíproco, y era muy evidente en aquel microcosmos social berlinés, a un lado y al otro del Muro.

En la sociedad del lado occidental, sin desaparecer del todo un cierto anti-americanismo ideológico, había cuajando muy pronto en la postguerra una peculiar simbiosis de dos universos morales históricamente muy diversos. A saber: bajo la impronta americana del plan Marshall (y, en los orígenes militares, del propio Truman) se había afianzado muy pronto la herencia socialdemócrata y "proletaria» alemana en la nueva situación política. La prueba más elocuente de este nuevo entendimiento era el éxito político y social que en su día había tenido Ernst-Reuter, el heroico alcalde (1948-1953) que había renovado con enérgica convicción en el «Berlín libre» de postguerra la común lucha por la justicia de los comunistas y socialistas del periodo de entre guerras. En la plaza que llevaba y lleva hoy su nombre, había y hay todavía una escultura alegórica a él dedicada. Se trata de una sencilla y vigorosa llama de hierro que ya nadie apagaría: «la paz sólo se preserva con la justicia». Siempre se le recordaba, y se le seguirá

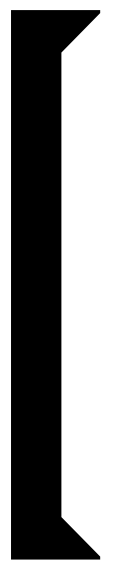

Se ha comentado con frecuencia que la compe-

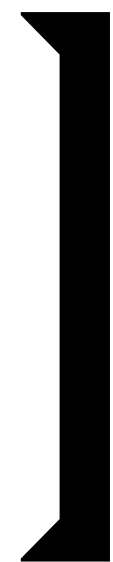

tencia ideológica asociada a la confrontación bi-

polar favoreció a largo plazo la introducción en

la democracia capitalista de formas de justicia

política distributiva, reivindicadas también, ob-

viamente, desde dentro. mada capital de la RDA, parecía más bien un empeño de la voluntad de poder para hacer oír su voz en el mundo. Avistada desde lejos, aquella Torre de Televisión, a la que nunca he tenido tiempo de subir, parecía ciertamente un ejemplo logrado de ocio moderno, similar al de otras ciudades; una antena para el ascenso local, pero sobre todo conectada por arriba con el mundo desarrollado. Pero sin raíces peculiares con el entorno ni con en el pasado.

Berlín era, pues, un mundo cargado de resonancias y connotaciones que uno no acababa nunca de escudriñar. Ahora bien: ¿qué diferencia irreductible separaba en rigor a Berlín Occidental de Berlín Oriental? Ésta no era una pregunta entre otras posibles sobre la ciudad, sino que formaba parte objetiva e imperativa de la vida de la ciudad. Era una pregunta que se apoderaba de uno y, quisieras o no, te forzaba a escrutar aquel concentrado mundo histórico, en el que el pasado, por así decirlo, se mantenía en una constante vigilia diurna y sin dormirse jamás. Letreros de calles ya intransitables, estaciones de Metro donde los trenes no se detenían, casas abandonadas, solares no construidos, ruinas preservadas por el azar y por la voluntad: todo traía constantemente a la actualidad y a la atención un pasado derruido y, sin embargo, insepulto, palpitante. ¿Por qué? Sencillamente porque, en alguna medida, el pasado se hallaba todavía indeterminado; «indeterminado», pues no estaba dicha su última palabra, su significación última, y uno seguía calladamente preguntándose dónde andaría a parar todo aquel choque de guerra congelada y distraída, y de voluntades en pugna, provenientes del Este y del Oeste, provenientes de la vida nacional alemana y de la vida europea e internacional.

\section{Cortas visitas, viaje casi interminable}

Cada verano hacía rigurosamente una visita al Berlín Oriental. Había que pasar el control policial rutinario de una burocracia tan interesada en la caza de la posible infiltración informativa y política como en la pesca del gravamen impuesto a los turistas, que inexcusablemente queríamos visitar el Museo Pergamon y echar una ojeada expectante al otro lado, gastándonos al menos el cambio de moneda obligado como precio de entrada: 25 marcos occidentales por 25 marcos orientales.

A una cierta escala parecía que tenías una pulsación directa del contraste mismo del mundo. Sentías, al cruzar, los dos ritmos temporales cardinales y protagonistas que marcaban, más allá de la división de Alemania y Europa, el entero ritmo histórico de la época en toda su dimensión. Pero en la frontera misma comenzaba una distancia real que resultaba intransitable: te topabas con un tejido social en cuyas relaciones humanas difícilmente podías penetrar si no eras miembros de aquella «comunidad humana socialista», por usar la expresión de 1963 de Walter Ulbricht como dirigente del partido del poder (SED) y del Estado mismo. Apenas si tenías acceso a un escaparate en cierto modo preparado, y no ibas más lejos en una visita tan breve; ni te enterabas de mucho más, ni te situabas dentro del juego o del ejercicio del poder. Sólo percibías que las emociones personales no entraban espontáneamente en las interacciones sociales. En el bar, el restaurante, en la librería, o la peluquería, no parecían tener ningún interés en satisfacer al cliente; los empleados, seguros de su puesto, se limitaban a cumplir una función y un horario, sin interés algu- 
no en el rendimiento del servicio público ni en la gratificación de los usuarios. Pero yo nunca sentí que detrás de aquel silencioso y regulado funcionamiento de las cosas, detrás y más lejos de aquellos modales vagamente militares de obrero funcionario, no sólo había una fe política diferente en la «buena idea del socialismo", sino que también finalmente había resignación y desapego al sistema; e inseguridad y desconfianza; incluso, mucha desconfianza. Una «desconfianza» que, como después he podido averiguar, surgida frente al poder incontrolable del Estado, había acabado calando en las relaciones interpersonales mismas alterando sus emociones sociales más básicas. Como solamente después he sabido, la fidelidad al sistema nunca parecía definitivamente probada y siempre podía ser cualquiera vigilado y denunciado por quien menos pensabas, y la denuncia se convertía en una prueba (meramente provisional) de la lealtad del denunciante con el Estado.

Pero, ¿cómo hubiera podido yo entonces llegar a penetrar en esta peculiar cadena de la subordinación social? Desde luego, podría haber logrado una mejor comprensión de la naturaleza del poder político, y de aquel poder político en particular. Quizás: pero yo entonces pensaba, de manera un tanto superficial, que el poder político consistía casi exclusivamente en una forma de control y ordenación de la vida económica, y no en un estatus de ventajas y privilegios. No caía en la cuenta de que una cosa es tomar decisiones para defender el socialismo y otra cosa ejecutar y obedecer estas decisiones, se crea o no en el socialismo. No podía sospechar, por tanto, que el poder político, regulado jurídicamente, pero sin el imperio de una ley propiamente constitucional, no sólo imponía un control coactivo sobre toda la sociedad, sino que alteraba la vida social en su raíz constitutiva, impidiendo la inserción de las actitudes personales en las relaciones sociales. Toda la vida social discurría conforme a pautas de ordenación política, y, sin embargo, no había comunicación interpersonal en primer plano ni comunidad política en última instancia detrás de aquella forma de organización social. El ciudadano no podía autocontrolar su propia conducta social, y se suprimía, con ello, la base de la reciprocidad, el intercambio o la libre cooperación, que hacen que una comunidad política tenga una capacidad de comunicación continua entre la vida personal y la vida pública, y en consecuencia una capacidad de autocontrol y autoresponsabi lidad colectiva. A pesar de mi curiosidad y de mi atención en aquellas formas de socialidad claramente diferentes, no percibí ni comprendí entonces nada de esto.

Tampoco sospecharía años más tarde que en aquel duro bastión alemán ( «la criatura preferida de Stalin» desde su nacimiento), se llegaría incluso a poner en marcha una resistencia organizada frente a la Perestroika de Gorbachov. Porque estas reformas animaban a la gente a perderle el miedo al régimen, y porque, la élite en el poder llegaría a comprender con temor que la reforma era una vía «ilusa»e «ingenua», que acabaría entregando el «desarmado socialismo» al "capitalismo», y a la "estrategia de Washington». Eran los años ochenta y la retórica marxista y socialista sufría una primera erosión generacional en todo el bloque del Este: sin originar, sin embargo, en la Alemania del Este ninguna oposición expresa al comunismo como en otros países socialistas. He sabido mucho después que algunos jóvenes se sentían alejados del poder, desilusionados y vitalmente fuera del orden; que se expresaban a veces en un soliloquio libre de la conciencia en la escritura o la escultura. Y que, al menos a partir de 1986, había discusiones iniciales en el interior de las iglesias protestantes sobre ecología y derechos humanos. Pero nada de esto era visible en una visita tan corta y tan mal preparada intelectualmente. En realidad yo contaba solo con una impresión básica que no me abandonaba nunca: en Berlín Occidental te llegaba siempre una cierta simpatía animada e instintiva desde el fondo de la sociedad; mientras que en Berlín Oriental, en cambio, la sensación era más seria y fría: el trato era correcto, pero no había apenas lugar para la espontaneidad o la camaradería (quizás sí la había, etimológicamente al menos, entre los camaradas que tenían la misma causa). Al visitante le llegaba un cierto talante rutinario de autocontrol y dedicación pero no sabía a que atribuirlo. Cuanto más te alejabas del centro más percibías las miradas contenidas de curiosidad y hasta de pesquisa propias de una atmósfera cerrada, de un país selectivamente aislado; después he sabido que, a pesar de su integración económica en el bloque del Este, no les resultaba fácil viajar ni siquiera a la Polonia agitada de los años ochenta. La cuestión era, pues, averiguar a qué diferencia de fondo y objetiva correspondían estas sensaciones y emociones tan diferentes que siempre me envolvían. Ello requería, en rigor, no sólo un largo viaje mental, sino también algunos cambios en mis propios esquemas conceptuales. Y sólo dos décadas después de la reunificación democrática de Alemania he podido sentir y advertir algo decisivo de lo que entonces nunca me percaté.

En primer lugar, y de manera imprevista me ha asaltado de frente el dolor y el sufrimiento que originó y acumuló también esta dictadura tan peculiar y que tan poco ha tenido que ver con las dictaduras nacionalistas e impuestas desde dentro de la sociedad, como el nazismo o el franquismo. Apenas si he tenido una comunicación directa con la población más afectada por la coacción del poder, pero me ha sorprendido, ante todo, la forma distante, escéptica, perpleja, a veces oportunista, y discreta, en que la mayoría de los alemanes del este se han adaptado a la democracia representativa, a las instituciones políticas y a la economía social de mercado del oeste. Han seguido desplazándose hacia el oeste para encontrar otras oportunidades, y la natalidad ha caído abruptamente. Han perdido una forma anterior de seguridad y no han ganado nuevas motivaciones: con poca expresividad, sin un consenso compartido sobre el pasado, sin compartir hasta la fecha un sentido de comunidad política. Como si estuviesen en cierto modo descontentos a la vez por el pasado y por el presente. Algunos todavía piensan con resignación que aquel proyecto político contenía una promesa de solidaridad y de justicia que, sin embargo, se truncó. ¡Después de veinte años de la caída del Muro, ninguna reflexión histórica "post comunista» semejante a la que se están haciendo desde Budapest o Praga! En Portugal o España la caída de las dictaduras y de sus apoyos fue más clara desde el principio, y vino acompañada de una oleada de vitalidad social antes reprimida: con el regreso de exilados y emigrantes y con la llegada masiva de capital e inversiones. De forma significativa, también en los otros países socialistas vecinos hubo desde el principio un cambio emocional más expresivo, pero en la antigua RDA no. Quienes acaban sufriendo la acusación de ser enemigos del Estado eran siempre sin falta quienes todavía soñaban con un Estado socialista democrático. Que el capi- 
talismo eficiente y social pudiese formar parte de la alternativa al sistema no lo debió pensar nadie de los que se quedaron hasta el final en la RDA. Es algo que sorprende al espectador y al visitante.

Contaré, pues, a qué interpretación final sobre el comunismo alemán he llegado en un periodo de más de treinta años, y, por qué he llegado a ella también tan tardíamente. Adelantaré, sin embargo, para aligerar el camino, algunos de los rasgos más generales del punto vista que tan trabajosamente he conseguido.

Según creo, lo que allí ha habido en juego ha sido, en primer lugar, una estrategia expansiva de la Unión Soviética, que supo encontrar su oportunidad en el enfrentamiento con la Alemania de Hitler sobre el allanamiento total del suelo alemán. El mito soviético pudo así renacer entonces de aquellas ruinas apoyándose en los comunistas organizados allí desde una época anterior. Fue una estrategia impuesta desde el principio a la población, contando, desde luego, con un importante apoyo: para ganar la guerra en primer lugar, y para salir después de las ruinas de la guerra con un moderado desarrollo material y social. A algunas capas de la

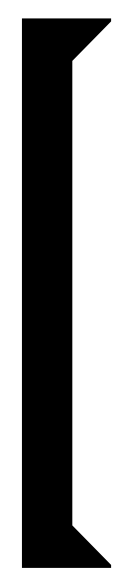

En rigor,en aquella socieddad de obreros y campesinos y trabajadores de la cultura (asíproclamada en los textos fundacionaless, y en aquel colectivismo organizado nohubolugaralgunoniparalaempresa moderna ni para el arte y la lírica libres

población les dio incluso oportunidades nunca antes imaginadas, pero el coste humano y cultural ha sido demasiado alto. Durante cuarenta años un rígido control social ha sido animado por una peculiar fusión de marxismo-leninismo economicista y de luteranismo moralista, que ha impedido un aprendizaje social e individual en la libertad y en la responsabilidad, revelados ya como muy pertinentes en la insegura República de Weimar. Pero el nuevo Estado militar, prolongación del Estado soviético no tenía, claro está, embargo, ningún interés en recuperar desde dentro este dramático precedente europeo. Se concebía a sí mismo como una prolongación de las «luchas obreras de los años 20», y al clavar, efectivamente, su semilla en una conflictividad social que se venía arrastrando en toda Europa Central, llegaría incluso a reactivar después con una técnica nueva el orden social autoritaria de la Prusia Oriental y de la Alemania Central anterior a 1914.

Han sido éstos procesos largos que escapan a la conciencia de los propios protagonistas. El propio lenguaje revolucionario e internacionalista y el propio desarrollo industrial y social han logrado ocultar hasta el presente esta regresión humana y cultural del Estado Comunista: en las creencias de la mayoría de sus ciu- dadanos y en los ojos de muchos observadores externos. En rigor, en aquella sociedad de obreros y campesinos y trabajadores de la cultura (así proclamada en los textos fundacionales), y en aquel colectivismo organizado no hubo lugar alguno ni para la empresa moderna ni para el arte y la lírica libres; ni para una moral responsable, ni para una exigencia de los derechos personales y civiles del mundo moderno. Producto de una socialización política extrema, resultó al final una sociedad en gran medida atrapada por expectativas irreales, sin capacidad de orientación. Carecía de un proyecto de futuro tanto por parte de sus gobernantes como de sus ciudadanos, y la maquinaria se paralizó sin una endógena oposición alternativa. He tardado mucho en darme cuenta de esta anomalía en una sociedad desarrollada y educada. Y todavía me parece no haber concluido argumentativamente aquel viaje emprendido en la búsqueda de las causas y razones que separaban y enfrentaban internamente a la nación alemana y a Europa en el mundo.

\section{En los dos museos: dos afirmaciones históricas y una misma pregunta sin respuesta cabal}

Mi reflexión comenzó a desarrollarse no en la calle ni con la ayuda de una historiografía académica, sino en los museos, que eran más bien una buena y elaborada justificación y propaganda del poder.

En efecto, siempre me demoraba pensativo en los dos Museos de Historia de Alemania: el de la RFA, en Berlín Occidental, y el de la RDA, en Berlín Oriental. Las fotos, los panales y los gráficos, los podías interrogar y tomar notas. Allí se ponía a prueba mi comprensión de la historia de Alemania y mi comprensión histórica del presente. Lamentablemente mis estudios de Historia y de Filosofía me resultaban insuficientes y deficientes para responder a las preguntas que me suscitaba la comparación de estos dos museos, separados sólo por un paseo a la altura de la Puerta de Branderburgo.

En los meses del verano, siempre había cola para entrar en el Reichtag, que desprovisto de sus funciones políticas, acogía una exposición permanente sobre la historia de Alemania. Se accedía por la puerta de atrás, por una entrada contrapuesta a la entrada principal, donde se seguía leyendo, disecado en el tiempo, el lema parlamentario inscrito allí en 1888: «Dem deutschen Volke». Eran una historia socio-cultural general, pero se ponía quizás el acento en las dificultades del parlamentarismo liberal-democrático que sólo tras la victoria de los aliados sobre la Alemania nazi había logrado vincular de manera estable el nuevo estado constitucional alemán con el mundo occidental. La atención se centraba, o al menos así creo recordarlo, sobre la oportunidad perdida, sobre la trágica escisión de la dinámica República de Weimar: su intensidad expresiva y cultural, pero también su agitada tensión e inestabilidad política y social. En Berlín, la capital, liberada de la vieja censura y del viejo militarismo derrotado, había sentido en los años veinte la ráfaga de una promesa de futuro, difusa y no siempre bien determinada, que parecía incluso prolongarse más allá de Alemania. La República de Weimar en Berlín logró algunos éxitos fugaces en medio de una tensión social que la sacaba fuera de sí. También se podía constatar en el museo la continuidad histórica con todo el pasado: la conformación de la nación en una época relativamente tardía, con referencia a 
los países de Europa Occidental, y el constante y conflictivo cambio de fronteras, es decir, el problema nunca resuelto de la unidad territorial nacional, que suponía además una gran inestabilidad en el proyecto político alemán.

Pero, retrospectivamente, tiendo a pensar, sin embargo, que el impacto y el horror del nazismo y de la Segunda Guerra habían desdibujado la dimensión cultural e imperial anterior a la Primera Guerra Mundial. No se intentaba explicar por qué acabó rompiéndose la colaboración de la monarquía y el liberalismo que había sido un rasgo tan peculiar de la primera ilustración política alemana. Efectivamente, a lo largo del siglo XIX, y sobre todo entre de 1871 a 1914, Alemania había logrado una pujante unidad nacional como Estado Federal y centralizado a la vez. Aunque la monarquía constitucional había silenciado la voz del pueblo, se había desarrollado un sistema estable de cinco partidos políticos y una notable cultura burguesa y popular, tal y como se reflejaba en la solidez del urbanismo moderno y metropolitano de Berlín. Sin embargo, el desastre y la expansión militar del nacionalismo belicista y criminal de Hitler impedían sopesar la identidad cultural, desvalorizando sin matices todo el pasado histórico nacional anterior, suprimiendo la complejidad y ambivalencia de la historia real.

$\mathrm{Al}$ acabar la exposición uno creía comprender bien por qué la Alemania de postguerra (en la República Federal) se había dedicado intensamente a la recuperación económica sin una gran vitalidad cultural endógena; obedeciendo y respetando la Constitución, pero sin darle ya más vueltas a las grandes preguntas filosófico-políticas, y sin mirar tampoco de frente, al menos al inicio de la post-guerra, a las motivaciones y al apoyo del Holocausto judío.

En contraste con esta, digamos, sociología histórico-política, al otro lado de la tapiada y postergada puerta de Brandemburgo, la sólida Universidad de Humbolt mostraba ante todo una, podríamos así llamarla, pedagógica historia social marxista de larga duración, que culminaba con la fundación en 1949 del Estado de la RDA vinculado al Estado heredero de la Revolución Rusa de Octubre. A pesar del peso indudable del partido comunista en Alemania, la sociedad alemana nunca había vivido, ni en el Este ni en el Oeste, nada parecido a la transformación espectacular de la Revolución Rusa. Pero esta exposición museística sugería que, en el largo plazo, el entero movimiento obrero europeo, bajo la dirección política de la Unión Soviética había acabado por imponerse finalmente sobre la fatal alianza de la dictadura de $\mathrm{Hi}^{-}$ tler con el capitalismo industrial y financiero. La ocupación en todo el Este de las áreas aliadas de la Alemania nazi se vinculaba allí a unas luchas sindicales y políticas muy anteriores, incluso anteriores a la existencia del movimiento obrero marxista. ¿Qué base objetiva podía tener esta perspectiva?

Objetivamente, el enfatizado antifascismo comunista tenía su gran parte de verdad: había costado demasiadas vidas, y la colaboración estable desde los años 40 de Inglaterra, América, Francia y de Rusia había sido decisiva para la paz en Europa y el mundo. Estos hechos me parecían fuera de duda, pero la comprensión histórica última de gran poder que había adquirido el comunismo no se veía ayudada, desde luego, por aquella exaltación ideológica. Se narraba la epopeya de una vinculación alemana especial con Rusia; no en clave cultural de un hipotético eslavismo germánico o algo similar, sino en una clave social y política: como lucha «anticapitalista» y en cierto modo «antioccidental». Y se sugería al mismo tiempo una tesis mucho más osada si cabe: aquella Alemania socialista y desarrollada del Estado de la RDA, que había tomado cuerpo dentro del orbe político-miliar de la URSS, tenía incorporada como herencia el «verdadero pueblo alemán, la verdadera Nación» alemana: era la Alemania con futuro liberada de su lastre burgués y clerical. Con este esquema y esta creencia era reconstruida una secuencia temporal y narrativa imparable: la guerra de los campesinos, la reforma protestante, la Ilustración científica y finalmente la cultura proletaria alemana, rusa, internacional.

Era una narración exaltada con visos de coherencia, pero en el fondo descabellada: ¿Cómo se podía sostener que el Comunismo había supuesto la victoria radical del Nazismo, capitalista y nacionalista, «arrancando sus raíces económicas y sociales», sin confrontarse directamente ni aclararse con las motivaciones antisemitas y estratégicas? Aquellos carteles, aquel lenguaje y aquella estética aproximaban, por el contrario, ambas formas de violencia visceral. Era mayor, ciertamente, la excitación histérica de las masas con Hitler, pero también acababa desapareciendo la voluntad personal en la colectividad comunista organizada. Una reconstrucción histórica que atendiese a la humanidad que se hallaba en juego requería un ensanchamiento de la perspectiva: hacia el pasado y hacia el futuro.

\section{¿Una perspectiva internacional y geográfica de la Histo- ria y de la Cultura?}

Hasta el final mismo de la Guerra Fría, y después de haber visitado desde el año 2000 los Estados Unidos, no comencé a conformarme una perspectiva propiamente internacional de la historia contemporánea, dándole más importancia a la situación geopolítica y a la ecología de las ideas. Reparé entonces en dos ideas principales que permiten comprender mejor la relación de historia de Alemania con la historia universal, incluyendo la constitución de los dos Estados alemanes durante la Guerra Fría.

En primer lugar, comprendí que la revolución rusa se había abierto paso, entre otras cosas, por el apoyo alemán en el desarrollo mismo de la Primera Guerra mundial. En efecto, en la crisis del zarismo, los disciplinados bolcheviques bajo la estrategia de Lenin recibieron el apoyo no sólo de los campesinos, obreros y soldados rusos, sino también de los simpatizantes socialdemócratas de izquierda de Alemania, y hasta del propio gobierno alemán. Los mencheviques, por su parte, recibían un apoyo mucho más lejano y débil de América, Inglaterra y Francia, y Lenin logró imponer su tesis de que este apoyo suponía la continuación de una guerra imperial ajena y contraria a los intereses del pueblo ruso.

Y, en segundo lugar, percibí la gran decepción que produjo en la vida intelectual norteamericana el entusiasmo con el que la Alemania pensante se lanzó en la Primera Guerra Mundial. Este entusiasmo nacionalista desmedido arrojaba una sospecha de irracionalidad política en la profundidad misma de la cultura y la filosofía alemana. Algo que venía de lejos: antes de querer abrirse paso en el escenario del poder mundial. En la espléndida tradición del idealismo alemán, que pretendía ser una superación del empirismo y del racionalismo, la ciencia moderna no había enca- 
jado bien, tampoco había una noción clara y positiva de ciudadano y de Estado moderno. En la creativa crisis de los años veinte y treinta se repitió esa espejismo: la élite intelectual (neokantianos y existencialistas) no se encontró en la mejor disposición para sintonizar con la República de Weimar, ni para evaluar, en particular, correctamente el alcance político de la Revolución $\mathrm{Ru}-$ sa. A muchos intelectuales influyentes («nacionalistas» $\mathrm{O}$ «internacionalistas») no les preocupa el precio de sacrificar la libertad política en el procedimiento revolucionario de resolución de los problemas sociales, mientras muchos sindicalistas obreros se entusiasmaban con el leninismo bolchevique que vio, desde el principio, en la Alemania industrial la puerta de entrada de la revolución internacional. Stalin no tuvo ninguna dificultad en prolongar esta tesis leninista. Y hasta el derrumbe mismo del comunismo (es decir: del comunismo soviético y del comunismo como sistema e ideario político), también yo había asumido implícitamente la creencia de que la Revolución de Octubre había sido poco menos que inevitable y, en gran medida, un gran avance histórico del que se habían derivado algunas consecuencias negativas más bien por una degeneración política posterior «estalinista». En mi caso, este juicio favorable sobre la causa marxista derivaba, sobre todo, de una cierta familiaridad, que databa del final del franquismo, con los valores políticos y académicos del marxismo en Italia y en Francia. No tenía entonces presente que Stalin mismo no era sino un desarrollo histórico posible, en las condiciones pre-modernas de la URSS, de la original teoría política marxista alemana.

Pues bien; al revivir de nuevo en aquellos museos la extrema confrontación social alemana surgida en el periodo de entre guerras, sentía como sí la confrontación que atenazó también a España en 1936-1937 (con Hitler y Stalin al fondo) no se hubiera resuelto ni disuelto todavía. El Muro, precisamente, me lo ponía así ante los ojos. En la Europa del momento y en la vida cotidiana el nazismo (derrotado) y el franquismo (consumado) eran ya historia lejana, y el comunismo parecía solamente la historia (quizás inercial) de otros con los que había que vivir civilizadamente. Sin embargo, el corte del muro interior se mantenía allí, dividiendo la ciudad y el país en dos historias ideológicamente irreconciliables, pero que, sin embargo, parecían haber conducido a resultados en alguna forma también coincidentes: en una exaltación del desarrollo económico, tecnológico y científico-natural en detrimento de la libre imaginación y de la vida, y de la política moderna propiamente dicha.

Salía de mi visita a los dos museos como quien sale de una sala de cine a las doce del día: con una extraña sensación de desajuste en el diafragma visual, y tenía necesidad de andar por un espacio abierto. Y, al proseguir el camino a lo largo de la Avenida de Unter den Linden, me encontraba en la gran explanada extendida entre el Palacio de la República y el Ayuntamiento, la estatua de Marx y Engel. Aquel volumen y grosor, magistral y bonachón, invitaba siempre a la fotografía de recuerdo: uno se veía acompañado de tan ilustres amigos. Me siguen poniendo de buen humor, y aunque parezca una asociación caprichosa, he de confesar que me recuerdan a D. Quijote y Sancho Panza, por el contrapunto físico de verticalidad y horizontalidad, y por la pareja de idealismo y materialismo. Sigo viendo en Marx, a pesar de su colectivismo antiliberal, un aliado posible del sueño anar- quista ingenuo y hasta juvenil de liberarse un día del poder político al suprimir la propiedad privada. Y, precisamente bajo esta imagen positiva, siempre me acudía a la mente la censura franquista y demonización de la obra de Marx. No se podía imaginar un contraste mayor de gustos y de convicciones intelectuales entre las dos dictaduras. Con una asociación mental añadida. Mi padre me había aconsejado siempre durante el franquismo la conveniencia prudente de ser apolítico: de no meterse en política, sobre todo cuando llegué a la Universidad en 1970. Y me pregunto y me preguntaba entonces: ¿habría alguien realmente apolítico en la RDA, con Marx y Engel en el espacio más visible, y con el Partico Comunista (SED) tan bien implantado socialmente y tan bien informado de todo?

Pues bien; a pesar de mi empeño reflexivo, tras comparar la historia política liberal occidental y la historia social marxista oriental, ni siquiera podía formularme con claridad la pregunta que inevitablemente estaba allí de fondo: ¿por qué en el proceso de modernización y de hegemonía (imperial y cultural) de Europa se había abierto paso en el Este, después de la súbita irrupción bélica de 1914, primero, la Revolución bolchevique Rusa (espectacular, antiliberal, antidemocrática), y a continuación la reacción (cruel, antiliberal, anticomunista), fascista y nazi, que acabarían, conjuntamente, dividiendo y marginando a Europa de la dirección política y cultural del mundo, quizás para siempre?

Cansado y satisfecho, pero también perplejo, volvía una y otra vez sobre un punto de partida que hoy puede parecer demasiado remoto: la disparidad interpretativa de las revoluciones urbanas europeas de 1848, que habían tocado levemente incluso a España, a pesar de su débil industrialización, apareciendo por vez primera la idea de un «republicanismo democrático». Me parecía, en efecto, que en aquella coyuntura comenzó abriéndose la gran escisión en la Europa continental que seguía atirantando al mundo: la primera división mental sobre la que un siglo más tarde se conformarían el Este y el Oeste políticos. ¿En qué sentido o sentidos fue decisiva aquella coyuntura?

La comprensión de aquellas agitaciones de Europa occidental, contemporáneas del Manifiesto Comunista, parecían arrojar, en efecto, dudas fundamentales a las que se le han seguido dando vueltas hasta tiempos mucho más recientes. Como ya he notado, la Historia en la RFA, tal y como se expresaba en el museo, insistía en la frustración política liberal de la revolución social desde abajo: volvía, pues, la vista hacia los revolucionarios de 1848 para recuperar ideales constitucional-parlamentarios. Mientras que la Historia contada en la RDA ponía el acento en los orígenes sociales de la utopía comunista radicada en la dinámica conflictiva del capitalismo industrial, y miraba, pues, a las barricadas de 1848 para afirmar una necesidad de revolución social obrera. Así pues, la pregunta de fondo a la que parecían responder ambas interpretaciones históricas dispares era saber si es posible el logro de una auténtica democracia republicana dentro del capitalismo, o acaso sólo en contra del capitalismo. Marx creyó a mitad del siglo XIX en la segunda opción, es decir, que sólo la autodestrucción política del capitalismo traería el reino de la plena realización humana. Embargado como estaba de la energía, la expansión comunicativa y la ilusión romántica de crear una nueva humanidad, penetró con inteligente pasión en el choque de la Francia revolucionaria y republicana y de la Alemania conserva- 
dora y monárquica, apostando por el progreso y la agitación frente a la reacción y al control. Pero, al mismo tiempo, se mantuvo impermeable a la dinámica evolutiva abierta por el capitalismo liberal inglés. Como casi todos los ilustrados alemanes ignoraba que la Ilustración británica y escocesa había precedido en casi dos siglos a la Ilustración alemana. La práctica reformista de los sindicatos obreros y la filosofía moral de un J.S. Mill desmentían con el pensamiento y con hechos el pronóstico marxista de la fatal y conveniente autodestrucción conflictiva del capitalismo industrial. Pero Marx, exiliado en Londres, después de la frustración de la revolución liberal-parlamentario alemana de 18481849, acudía a la biblioteca pública para desarrollar su esquema social «conflictivista» sin percatarse de la dinámica de la sociedad del entorno.

De manera en parte análoga, mi cabeza, bajo el influjo perdurable de la experiencia freudo-marxista del 68 y del estructuralismo de la Escuela de Annales, absorbido en la Universidad de Barcelona, tendía a exagerar el papel, no del conflicto, pero sí de las fuerzas impersonales en el curso de la historia (el instinto vital, las fuerzas económicas), en detrimento de la acción social del Estado, es decir, de los procedimientos de la democracia, descrita entonces en los medios universitarios de «izquierda» también, al modo de Marx, como «democracia formal». A pesar del impacto de la transición democrática en España, seguía yo por inercia sin razonar en términos de las variedades sociales del capitalismo, y no acababa por introducir correctamente la realidad de los valores en la acción social. Temperamentalmente, quizás la mía no era sino una forma descomprometida de objetividad que desconfiaba del humanismo por idealista y postergaba la responsabilidad concreta. Esta actitud (tal y como ahora lo pienso) se llevaba sin duda bien con una prolongación excesiva del compañerismo erótico en mis relaciones personales: vacacionales, por así decirlo, de manera permanente; una demora excesiva en la vida personal en detrimento de la madurez profesional y la responsabilidad política. Creo que a pesar de haber leído ya la aguda crítica empírica y política de F. Furet (1978), me hallaba metodológicamente aún bajo el esquematismo apriorístico de un A. Soboul, asociando en exceso la necesidad histórica de la Revolución Francesa y de la revolución rusa, unidas ambas por un continuo y análogo ímpetu y pathos. Y por razones diferentes, pero en cierto modo análogas, seguía, pues, ignorando (también yo como tantos continentales) las consecuencias históricas de la inicial modernidad política inglesa, y la fuerza insustituible del derecho, la libertad y la opinión pública. Diríase que ni siquiera había asimilado bien las lecciones de la propia transición política española. Tampoco me había percatado de los peligros de sacrificar la libertad política en los intentos de solución voluntarista y autoritaria de la cuestión social, pues ignoraba en ese tiempo las advertencias de Hanna Arend y de Ortega y Gasset.

Con estas limitaciones conceptuales y aquellas disposiciones generacionales y personales, no lograba una respuesta cabal sobre la naturaleza ambivalente del comunismo: su peculiar combinación de progreso material y de reacción política y cultural. No podía, en rigor, aclararme por qué el comunismo, que se había extendido con la necesidad de un delirio enérgico, aprovechando las rupturas sociales y políticas de 1917 y 1945, formaba todavía parte constitutiva del anclaje del mundo histórico del presente. Había que contar con él, eso era todo. La realidad histórica del Muro, más allá del cemento que separaba ambos museos, quedaba, pues, atrapada ante mi mirada en un cierto laberinto, y no podía avanzar mucho más en estos razonamientos. Creo que, básicamente, carecía entonces de un mapa mental de la situación geopolítica de las ideas: la embajada bolchevique de Lenin en la República de Weimar actuó desde el principio en contra del modelo constitucional de Francia e Inglaterra. Apenas si podía compartir estas reflexiones con estudiantes, más jóvenes que yo y cada vez con menos interés en la política. Pero la vida trascurría lo suficientemente atractiva y entretenida..., aunque no sin sorpresas.

\section{Súbitas impresiones irresistibles: algo básico no funciona en aquella dictadura tan pertrechada y seria}

La sorpresa y el estímulo acuden a nuestra vida sin que los llamemos; no tienen que suceder grandes cosas, a veces pequeños detalles tienen consecuencias imprevistas. Mi soliloquio sufrió un primer empujón desde fuera en estos dos momentos contrapuestos: mi primer descanso pensativo en Alexanderplatz y el sonido de un disparo súbito que resonó en mi propia ventana a plena luz del día. A estas impresiones siguieron otras indicaciones e intuiciones que irrumpieron sin aparente razón de ser, y que acabaron por descabalgarme de mi cómoda perplejidad obligándome a revisar mis concepciones históricas de fondo y a atender a hechos concretos hasta entonces ignorados.

Recuerdo la desolación casi fisiológica que me produjo la primera vista sobre Alexanderplatz. No era simplemente la desaparición del pasado histórico, una nostalgia, de la consistencia arquitectónica de la metrópoli europea los años 30, digamos, del mundo evocado por A. Döblin, pues esa destrucción afectaba en general a toda la ciudad. Tampoco era sólo el urbanismo funcional sin gusto y pretencioso de todo el conjunto, pues con ese estilo sin estilo ya estaba bien familiarizado desde el propio desarrollismo franquista en España. Lo que me llamó poderosamente en aquel espacio público rediseñado por la RDA fue algo que pudiera ser trivial o intrascendente: unos grupos de visitantes, quizás provenientes de los otros Estados Socialistas de Europa del Este, que por allí deambulaban tratando quizás de comprar o de tomar algo. Instintivamente escribí en mi cuaderno de notas: «masas asiáticas». No sé ni siquiera por qué empleé la palabra «masas», pues eran muy pocos para tan gran espacio, y la expresión parece desde luego gratuita y extemporánea; y, ¿por qué «asiáticas» ? Para mí, aquél era el punto más oriental del mapamundi que contemplaba y sentí la sugestión extraña e incontrolable de que aquellos grupos dispersos que se movían desangelados y sin gran animación eran el mayor contraste que podía imaginar con el bullicio turístico, digamos, de una plaza renacentista de las ciudades italianas que había visitado poco antes. Me trasmitían una sensación de cierto desajuste con un entorno físico sin perspectiva arquitectónica fija, y esta extrañeza subjetiva recayó fatalmente, en un juicio injustificado, sobre el entero orden social de las «democracias populares».

Cuantas veces regresé a la plaza volví a sentir una insatisfacción análoga: unas veces, al ver a jóvenes queriendo matar su aburrimiento y refrescar las piernas en una fuente central de una cierta dureza, mientras eran amonestados y disuadidos con paterna- 
lismo rutinario por la policía; otras, al tratar de descansar en alguna cafetería después de haber pasado un rato en las librerías del entorno tratando de encontrar algo interesante. La filosofía apenas si comparecía, y para sorpresa mía, entre las publicaciones marxistas nunca encontré nada equivalente a la viva historia social marxista inglesa de un E. P. Thompson o un E. Hobsbawm, donde la experiencia personal prendía activa en las relaciones sociales; en el historiador de la RDA no comparecía la vida humana concreta. Se acumulaban, pues, mis sensaciones negativas $\mathrm{y}$ acabé diciéndome o repitiéndome pensamientos de otros a los que antes no le había apenas crédito: el comunismo quizás no era originalmente el nihilismo materialista que algunos denunciaban, pero ciertamente parecía un idealismo equivocado. En el ejercicio histórico del poder había impuesto un orden jerárquico y una forzada e inhumana subordinación de los medios a los fines, y ahora parecía sólo vigilar un bienestar cotidiano más bien aburrido. Distanciado yo también del entorno, me sumía siempre en una cierta evocación histórica: la brutalidad con la que el Ejército Rojo había acabado en este solar con la inhumanidad del poder $\mathrm{Na}$ zi en 1945 parecía completamente cancelada. Nadie parecía ya estar dispuesto a volver a ninguna forma de violencia, pero la bús-

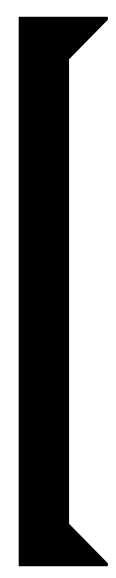

La realidad histórica del Muro, más allá del ce-

mento que separaba ambos museos, quedaba,

pues, atrapada ante mi mirada en un cierto la-

berinto, y no podía aranzar mucho más en estos

razonamientos.

queda de un bienestar material sin espontánea comunicación me trasmitía allí una lasitud algo triste.

No sé cuánto tiempo transcurrió; ni siquiera si fue el mismo verano, el siguiente o el anterior, cuando un día, quizás a media mañana, desde una de las ventanas de un cuarto piso de Leutschnerdamm (¿19?), no lejos de Oranienplatz, salió un grito desgarrado: ¡asesino! Me pareció un híbrido fonético de alemán e inglés (murder/moërder) que parecía prolongar a un disparo inmediato anterior menos audible, seguido de un cierto movimiento de coches al otro lado del mundo. Prosiguió un silencio y nada más en claro pudimos sacar ninguno de los estudiantes extranjeros que acudíamos con curiosidad a Berlín. Tampoco recuerdo si al día siguiente los periódicos informaron sobre cómo acabó el intento de fuga, si con la muerte o con la detención del desertor del régimen. Pero alguien estaba alertado: ¿quizás algún artista procedente de la propia RDA refugiado allí desde las décadas pasadas? Quedó claro que la barrera no era solo un sistema físico de obstáculos, de patrullas móviles y de minas: era efectiva por los posibles disparos. Y nuestra ingenuidad de ver en Honnecker la sonrisa fría de un dictador inofensivo, que, en su día quizás también se había enfrentado a Hitler saltó por los aires. Las armas apuntaban y disparaban, aunque sólo fuera contra los propios ciudadanos. Parecía, en efecto, como si la guerra (en rigor: ¿qué guerra la de 1914 o la de 1945?), que tantas huellas había dejado en la ciudad no se hubiese apagado del todo al otro lado. Quizás muchos alemanes, en ambos lados de la Nación, tenían experiencias y sentimientos más controvertidos y dolorosos, pero a mí simplemente me llegaba un difuso sentimiento de guerra meramente apagada por la rutina, una cierta sensación de sofoco y hasta de ahogo. No llegaba perezosamente a reconocer, sin embargo, que la implacable inhumanidad empleada para lograr objetivos, erigir y mantener un orden nuevo no había desaparecido del todo. Era lento, pues, en poner en relación coherente aquellas sensaciones inmediatas con conceptos y con lecturas. La mente humana tiende a ser por inercia banalmente inconsecuente; tiende a concluir, pero se demora. Algo análogo sucede con las interrupciones de la vida colectica.

\section{Un pasado que no acaba nunca de concluir}

Unos veranos después, una tarde de agosto, al correr una de las ventanas de Lindenstrasse, que daban a Springer Verlag (es decir: entre Moritplatz, por la derecha y Kochstrasse, a la izquierda), sentí, o acaso recordé sentir, un inesperado aroma de rosas que me echó fuera de casa para refrescarme con cierta nostalgia. Por aquel entonces había comenzado a identificarme más con el paisaje urbano y la historia cultural, y salía a veces a leer a algún lugar de la ciudad. Pasé aquella tarde a pie cerca del CheckpointCharlie, sin prestarle atención alguna a la rutina turística y burocrática del paso de frontera, y me adentré finalmente en el Tiergarten. Descubrí algunas estatuas en las que nunca había reparado, y de pronto, una rosaleda en su plenitud florida. Permanecí de pié, me senté en un banco, miré al poniente, y el Sol no enrojeció ni se tornó rosa ni violeta ni amarillo siquiera, sino que, en un cielo cubierto de neblina, lentamente se marchitó. En la Filarmónica resplandeció por poco tiempo su cobre viejo. No había nadie en el entorno; oía mis pensamientos. A la vuelta, para ganar más luz anduve por el límite del parque en paralelo al muro que estaba en frente, andando en línea recta luego. Casi anochecía y tenía muy presente la vez anterior que algo más tarde, y pesar de las picadas de los mosquitos, había regresado también por allí (viniendo entonces desde la explanada del Reichstag) en compañía tan deliciosa. De pronto, el camino que antes me supo recogido e íntimo ahora me parecía cerrado y áspero, y sin ninguna otra razón culpé a aquel muro recto y frio sobre cuyo cemento (por aquellos años ya aparecían los grafitis), no podían ni siquiera descansar las primeras sombras. El Muro se mantenía allí constante por mi lado izquierdo empequeñeciéndome la noche... con un olor imposible de rosas secas en el aire. Encerrado en mí mismo, asocié el nombre de Potsdamer Platz a la embrujada noche de E. L. Kirchner: el azul nocturno, femenino, marino, elegante, lujoso de 1914 se apoderó de mi mente con cierto gozo mientras me acompañaba sólo el Muro. El Muro había crecido precisamente sobre el vacio de la destrucción, sobre una separación impuesta en el corazón mismo de la ciudad, fortificando aquel páramo producido por la guerra: un espacio desolado y yermo donde antes había hervido una intensa comunicación, trenes, 
tranvías, hoteles, teatro: la sensualidad veraniega de la noche continuaba siendo negada para todos.

Al regresar a casa, ensimismado y melancólico, recibí la propuesta de ir, quizás al día siguiente, al «otro lado» en el coche de la mujer de mi amigo que trabajaba en la embajada de España en la RDA, y que por eso siempre alquilaban la casa de residencia familiar muy cerca del muro. Era una oportunidad estupenda, que facilitaba el tránsito y me permitía moverme con más facilidad por el Este de la ciudad. A mediodía, después seguramente de la jornada laboral, fuimos a descansar a la casa que esta funcionaría tenía en Leipziger Strasse, aunque no la habitaba. Ya estaba al tanto de la calidad de aquellas viviendas de bloques prefabricados y no me produjo ninguna impresión particularmente negativa, a pesar de que se empeñaban en contarme no sé que de la cisterna del cuarto de baño propio y de la del vecino, quizás no tan ajenas, la una respecto de la otra. Pero, en un momento me asomé al balcón para mirar a la calle. Debía ser algo así como un quinto piso, y pude ver el suelo de la acera de la calle directamente bajo mis pies: había una juntura no cerrada, una rendija abierta en el suelo del balcón, que era, sin duda, original. No debió encajar bien desde el principio y ningún inquilino hasta entonces se había tomado la molestia de rellenarla. En la España franquista y post-franquista, las viviendas de protección oficial a veces se entregaban también mal rematadas, pero el primer usuario no dejaba de retocarla a su gusto por todas partes. Aquel descuido en el balcón no era en absoluto peligroso ni molesto; en una calle con tanto tráfico, nadie se asomaría tal vez fuera. Pero me reveló una falta de amor extrema por las cosas, que no podía ser sino una extensión de un cierto desamor humano. No lo comenté con nadie ni establecí más comparaciones, y como se ve, no lo he olvidado. Años después he podido constatar (en Karow) que los agraciados que recibían del Estado una casa con jardín le dedicaban todo su tiempo libre, refugiándose en este caso en la vida doméstica, completamente desentendidos y ajenos a la vida cultural y pública. Esto no me ha hecho cambiar el juicio, y he seguido pensando, quizás exageradamente o sin pruebas empíricas suficientes, que aquella dictadura tuvo el tiempo para ello y logró alterar capacidades sensitivas básicas de la vida porque penetró en todas las actividades humanas y sociales, en la producción y en la educación; eliminando la pequeña propiedad campesina y la autonomía de la burguesía urbana, y forzando una forma de implantación de la mujer en la producción que llegó a atrofiar la relación narcisista con su propio cuerpo. Una dictadura menos activa no hubiera logrado anular el placer intrínseco que sentimos en cuidar el entorno que habitamos. Aquella dictadura industrial puso toda la fe en un futuro abstracto y colectivo, arrebatando el sentido de la responsabilidad personal en el trabajo y en la vida; un marxismo algo protestante sería su expresión doctrinaria, en contra de la original ética weberiana del trabajo vocacional, de autocontrol individual y de responsabilidad social.

He olvidado decir que esperábamos allí la visita de una joven de la RDA, que hablaba español correctamente y que tenía interés en conocerme. Creo que nos vimos alguna vez más; tenía cursados estudios de Arte y había trabajado recientemente en relación con alguna exposición de pintura. Vestía muy bien y era muy desenvuelta y curiosa. Le envié desde España por correo un artículo mío sobre anarquismo andaluz, y me contestó con una car- ta muy afectuosa, encabezada por un pequeñito dibujo con la silueta urbana de Mercedez Benz y la luna, como si la hubiese escrito mirando hacia el Oeste desde su escritorio. Sugería que, precisamente, unas gotas de anarquismo serían buenas para «renovar el socialismo». Poco después de la caída del Muro, creo que en el verano del 1991, reg resé a Berlín solo unas semanas. Había seguido como tantos otros casi en directo por televisión distintas imágenes de los ciudadanos del Este rompiendo la presa, pasando la frontera, abriendo brechas, saltando y subiéndose en el $\mathrm{Mu}$ ro, en una expansión que detonaba más el final de una sujeción que la consecución de una meta: nervios, euforia, fiesta, tensión a veces, pero no violencia. Logré hacerme de su teléfono y la llamé, lleno de curiosidad por ver cómo había vivido el cambio, es decir, el desmoronamiento del Régimen de la RDA, consecuencia del desmontaje en parte involuntario que había realizado Gorbachov del Comunismo soviético. En un momento, pues, todavía anterior a las primeras elecciones que conducirían a la reunificación. Estaba muy nerviosa y esquiva, y sin venir a cuento me preguntaba si yo sabía bien inglés y si había visitado Norteamérica. Quizás tenía algún viaje en perspectiva hacia Norteamérica y estaba ya mentalmente en la senda de cumplir con el nuevo deber

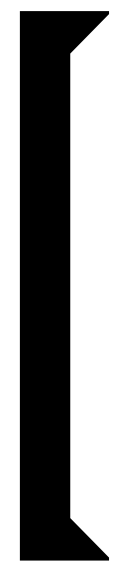

Al regresara a casa, ensimismado y melancólico, re-

cibíla propuesta de ir, quizás al día siguiente, al "otrolado" enelcoche delamujer demiamigo que trabajaba en la embajada de España en la RDA, y quepor eso siempre alquildban la casa de residencia familiar mus cerca del muro.

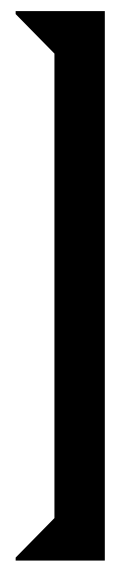

de la adaptación occidental, pero el hecho es que rehuía claramente a hablar del pasado. Ante mi insistencia, accedió a darme una cita en una dirección para mí casi desconocida. Me dirigí allí con sus indicaciones y no la encontré, y, después, no me devolvió tampoco la llamada. Supe, pasados unos días, al preguntar por ella, que había roto con su compañero, pues, en los días de resquebrajamiento del poder (desde diciembre de 1989 hasta quizás el 15 de Enero de 1990) éste había tomado parte activa en la ocupación de la Central de la Stasi para evitar la destrucción de sus archivos. Cuando regresaba de la fallida cita, al pasar por las residencias mejor acomodadas del antiguo Este, que de pronto ya no eran sino las del centro de la ciudad, reinaba el silencio y la inhibición de quién ha sufrido un shock y trate de reincorporarse; nada parecido había percibido antes del cambio. Era claro que el desbordamiento hacia el Oeste que había mostrado la televisión con la ruptura del Muro no provenía de todos los sectores sociales; a muchos otros les rompió su comodidad, su modus vivendi y sus expectativas. En Berlín Occidental, por aquellos días, todavía perduraba la sorpresa y hasta la celebración, pero quizás 
la actitud más extendida era ya la indiferencia; como si se dijeran: ahora les toca a los del Este hacer la reeducación democrática que el Oeste hizo en la postguerra. Tampoco comprendían que su propia identidad histórica requería una reconsideración. Mis amigos de Hannover seguían en su tiempo libre viajando hacia el Mediterráneo, sin ninguna preferencia especial por visitar Weimar, Dresde o Leipzig, y recuperar un diálogo interrumpido por décadas con su propio pasado histórico.

En los días siguientes seguí dándome grandes caminatas solo por la ciudad. Empezaba ya una cierta actividad constructora, que llegaría luego a ser frenética en Friedrich Strasse, por ejemplo. Pero en aquel momento, mi centro de atención era el espacio inerte que había dejado el barrido del Muro: allí tenía que acudir de nuevo el riego sanguíneo. Cerca de lo que creo que era un pequeño cementerio abandonado, que se había mantenido, precisamente, en la tierra de nadie entre el verdadero Muro y la frontera interior que frenaba preventivamente el acceso, un grupo de jóvenes actores o estudiantes de teatro había tedido la espiritual idea de montar una lectura de F. Schiller. Se anunciaba el acto con el rótulo tal vez de «Testamento de Schiller» o algo parecido, escrito en una pequeña tabla horizontal sostenida sobre una estaca clavada en el suelo; unas sillas plegables, una luz de batería y su voz clara, emotiva, militante, que parecía renacer de los libritos sostenidos por sus manos. Además de ganarse unos valiosos marcos nuevos con el ticket que vendían a turistas y a alemanes, recreaban en una atmósfera de verdadera religiosidad el fondo emocional común de la identidad cultural alemana que había perdurado bajo la división política. La vibrante voz del poeta dramático revivía en el pueblo, de manera individual y como coro colectivo.

Cuando más tarde he tenido la ocasión de leer y de escuchar a Joachim Gauck (el pastor protestante que se distanció un día en Rostock con valentía del Sistema y que ha sido actor político destacado en todo el proceso del cambio) no he dejado de pensar que con toda probabilidad su verdadero coraje ético y cívico no lo nutra ni la vieja fe de Lutero ni la cultura política moderna, sino algo anterior y más perdurable en el tiempo: el amor a la vida, a la familia, a la naturaleza y al trabajo bien hecho. La herencia cultural y moral del cristianismo, sobre todo en su versión protestante, se ha reactivado, no porque la población crea todavía en la historia bíblica de la creación y de la salvación, sino porque en el espacio público de las iglesias protestantes se reafirmó una socialidad y una comunicación no condicionada ni bloquea- da por el poder. No me parece azaroso el título de sus recientes memorias, y su tesón y primor por la escritura («Invierno en Verano-Primavera en Otoño»). La tradición popular y poética alemana se albergó no sólo en la lírica o en la prosa (que se debatía entre los grupos minoritarios que no encontraban editor y las publicaciones de cultura proletaria del sistema), sino también en el medio socializador que la iglesia evangélica preservó a pesar de haber colaborado con el Estado. La doctrina bíblica de la caridad solidaria coincidía con el socialismo en el rechazo del «egoísmo y la avaricia capitalista», pero la inclusión de la Iglesia (reorganizada en el Este desde 1969) en el Socialismo rompía a su vez el desmesurado monopolio ideológico de la dictadura política

En cambio, la creencia política en el «socialismo democrático», que con tanto desparpajo y retórica mantiene públicamente Gregor Gysi, sí me parece expresión de una experiencia cultural

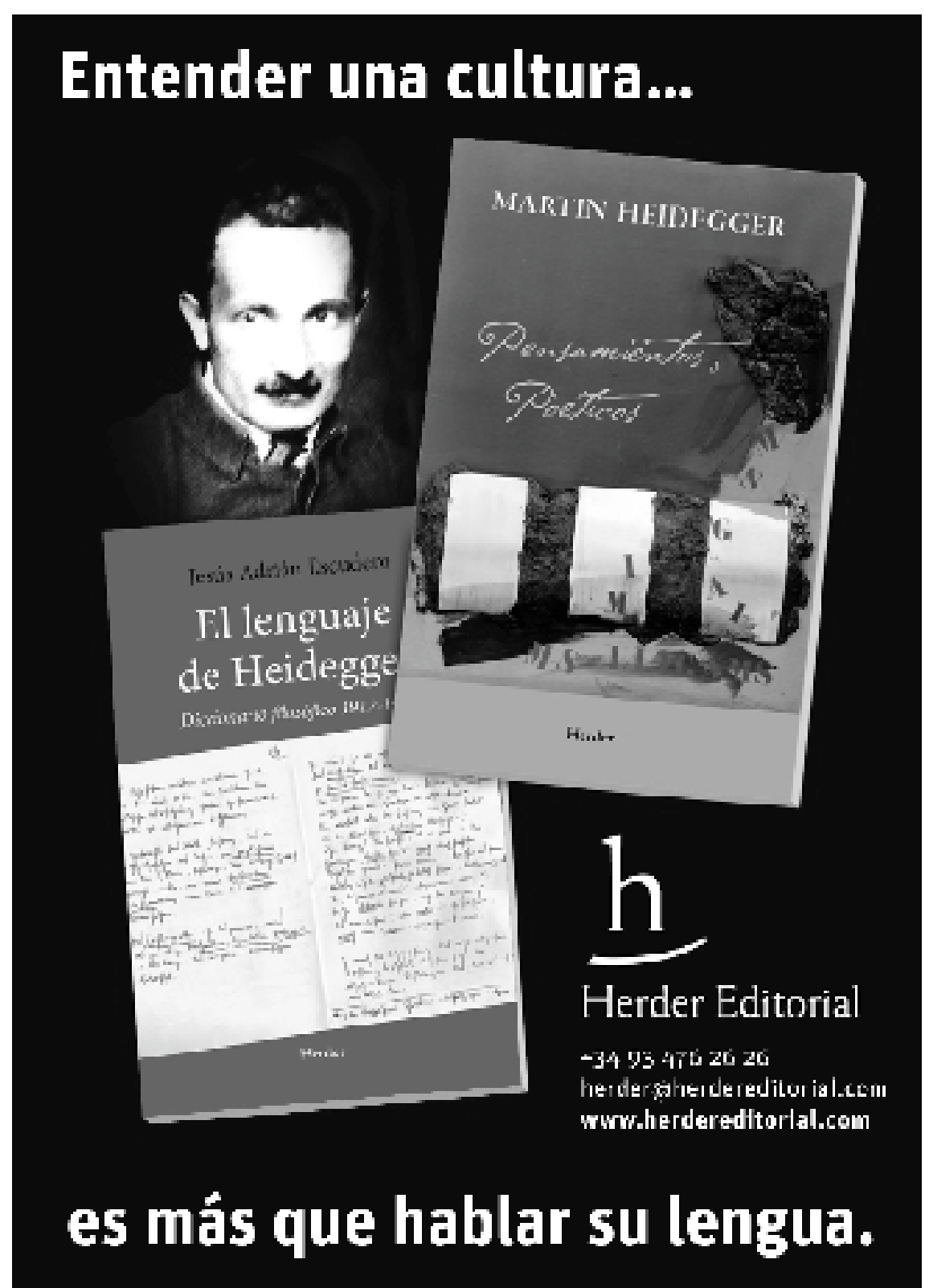


conformada inicialmente durante la dictadura de la RDA, pero, en cierto modo peculiar, a su vez, de una cierta actitud antiliberal de toda Alemania. ¿Cómo es ello posible?

Con ser ciertas y quizás sinceras las raíces en el periodo de entreguerras, la estela heróica de Rosa Luxemburgo y Liebknecht le han servido de mucho al habilidoso líder. En primer lugar de camuflaje populista y de izquierdas para la preservación de las propiedades y de clientela de la élite política comunista. Eso explica su hábil trascurso y mutación desde el seno mismo del SED, desde el momento inicial de su descomposición, hasta su liderazgo actual en el partido de la Izquierda (Die Linke), excepcionalmente bien implantado ya en toda Alemania. En paralelo a la necesidad psico-social de digerir el daño causado por la vigilancia organizada del aparato estatal de la Seguridad (Stasi), una herencia de la herencia de una dictadura en la actual esfera pública constituye, en primer lugar, una peculiaridad histórica de la RDA. Nada parecido permaneció después de los 12 años de violenta agitación del Tercer Reich, porque acabó derrotado. Y nada parecido ha permanecido en otras dictaduras más prolongadas, pero con medios menos eficientes de socialización política. El «partido de Gysi» ha explotado y explota sentimientos sociales y anticapitalistas sinceros al tiempo que evita que se recuerde y se juzgue la acción vejatoria del antiguo Estado y de sus colectivizaciones forzosas con el argumento de que se «reabre el lenguaje de la guerra fría». De esta manera gran parte de la élite dirigente y de los funcionarios del desaparecido Estado participan en las nuevas instituciones económicas, sociales y políticas democráticas, y se ven así forzados a ganar un sentido nuevo de la realidad. Pero el motivo más claro de su éxito es una forma de reelaboración de la identidad política del lado Oriental de Alemania. La mayoría de los alemanes de la antigua RDA se identifican nacionalmente como alemanes del Este; en cierto modo se han replegado ahora sobre sí mismos, aunque se sienten vinculados al Estado Alemán y a la actual capital política de Berlín. Es un juego ambivalente que tiene que ver con las décadas de experiencia política propia, pero también con el estado presente de toda Alemania zambullida en la globalización. O. Lafontaine ha tenido una habilidad psicológica convergente: ha reconducido los descontentos socialistas del SPD bajo la política conservadora liberal del gobierno de Schöder a una inesperada fusión con los socialistas excomunistas de la RDA. Se ha reactivado, así, una escisión surgida en el movimiento obrero durante la República de Weimar: entre sindicalistas reformistas que contribuyen notablemente a la consolidación de un Estado social constitucional y sindicalistas utópicos animados, ahora sobre todo, por un "pacifismo" antiamericano y anticapitalista, que afecta al mundo universitario y siembra dudas en el proyecto europeo.

Pero, es un hecho que el pasado de la RDA es ahora también el pasado de todos los Alemanes, y en cierto modo concierne a los todos los europeos. Lo que fue un error histórico en los comunistas alemanes plegados a la Rusia soviética puede debilitar todavía hoy la democracia europea si no se reelabora críticamente. Una anécdota ayudará a ilustrar lo que quiero decir.

Desde 1968 se inició una cultura ecológica que renovó la cultura política en la desarrollista RFA. También la protección de la naturaleza y del medio ambiente era «un deber del Estado», declarado así en la Constitución de la RDA. Y tan tempranamente como en 1972 se creó en la RDA un Ministerio de la Protección del Medio Ambiente y de la Economía del Agua. Pero cuando comenzó a organizarse allí un movimiento social ecologista cívico acogido en el espacio interior de la iglesia, las Fuerzas de Seguridad del Estado no tardaron en allanarlo en Berlín el 24 de Noviembre de 1987.

El Estado autoritario y cientifista llevó a su extremo el ineficiente fanatismo de los principios; usaba atractivos fines sociales no para resolver problemas sino para controlar a la sociedad; si en el proceso de realización de estos fines la sociedad le daba la espalda, no dudaba en aplastar a la sociedad. La tecnocracia autoritaria de la RDA promocionaba el desarrollo de la ciencia y de la técnica como un mero factor de desarrollo económico, como una capacidad instrumental sin finalidad ética y política. La ineficiencia que acecha todavía en la Democracia es diferente, pero también interrumpe la continuidad de los medios y de los fines: los dirigentes políticos dependen ahora de los votos y de las encuestas de opinión, y los agentes sociales se convierten fácilmente en espectadores. Con la reciente inserción de la RDA en el sistema político de la RFA parece haber mutado la politización anterior inducida desde el Estado en apoliticismo y desentendimiento de los asuntos públicos nacionales e internacionales. Los nuevos ciudadanos del Este se hacen un poco las «víctimas» de la política occidental que «los excluye», o del siempre conjurado y en permanente crisis capitalismo mundial. Resulta difícil, así, crear un nuevo entendimiento entre el Mercado y el Estado para la regulación financiera internacional y el desarrollo sostenible.

\section{El regreso a la historia con futuro}

Desde un punto de vista europeo, con la reunificación democrática de los dos Estados Alemanes de postguerra tras la «revolución pacífica» de 1989/90, Alemania ha conseguido finalmente realizar el sueño que recorrió el continente europeo en la ola revolucionaria de 1830-1948: la conjunción de la unificación nacional y de la libertad política como dos objetivos inseparables. Pero, desde una perspectiva universal, esta reunificación nacional democrática, encajada en la Unión Europea y en la OTAN, ha supuesto además la reinserción de toda la sociedad alemana en el curso único de la historia cultural humana, y no sólo en el proceso de globalización. Lo que salta ahora a la vista, en primer plano, es el excepcional aislamiento cultural que ha sufrido durante cuarenta años largos (de 1949 a 1990) esta zona de Alemania y Europa Central que con tan significativo acento ya vivía en los años veinte y treinta conectada a las innovaciones de la historia universal. Con razón se siente hoy Alemania finalmente reconciliada consigo misma y aceptada, querida y hasta admirada por sus vecinos y en el mundo. Ha logrado estabilizar a comienzos del Siglo XXI una comunidad interior tolerante y una convivencia exterior pacífica. Su economía, su investigación y su diplomacia han cobrado peso. Hay razones, digamos, alemanas, europeas e internacionales, de esta excepcional demora, que se podrían subsumir en la expresión conceptual de la "cuestión alemana», denotando así su carácter problemático. Ha sido una anomalía que la nación de mayor peso en la Europa Continental consiga en último término su normalidad política, después de haber ensayado en vano vías excepcionales de instalación en la comunidad internacional. Pero ello ha sido también una consecuencia de 
su ubicación geopolítica activa en el largo plazo: visualmente, entre Paris y Moscú.

Podríamos identificar así los sucesivos trenes perdidos de este demorado viaje de normalización política nacional e internacional. En primer lugar, fracasó la generación romántica y hegeliana post-napoleónica al querer sustituir desde el comienzo un Estado Constitucional por un nacionalismo cultural reformista. Al fracaso del movimiento liberal-democrático de 1848/49, siguió el equivocado empeño de la Monarquía imperial populista en solucionar la cuestión social con un paternalismo estatal sin libertades políticas plenas. La República de Weimar, que se abrió pasó con la derrotada nación monárquica en 1914-18, volvió su mirada y puso su más precioso empeño en un renacimiento cultural y en una agitada creatividad sin apenas cultura jurídico-política democrática. En Berlín logró construir preciosas viviendas modernas para la población necesitada, pero las necesidades sociales eran desbordantes, y se agitaba el odio y la frustración nacional por el trato de los vencedores, mientras el viento del Este se cruzaba constantemente con el viento del Oeste. Posteriormente, el terror Nazi, padecido pero también apoyado, y el estalinismo de la DDR, sufrido religiosamente pero no abiertamente re-

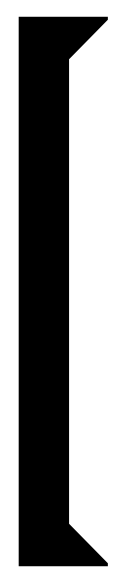

Al regresara a casa, ensimismado y melancólico, re-

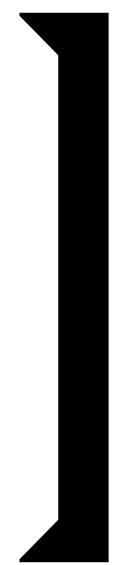

chazado, constituyeron un doble tributo demasiado alto y doloroso por el largo error de haber puesto en cuestión la sabiduría convencional occidental más razonable que demandaba la conciliación de la identidad nacional y de la soberanía con una estructura política democrático-liberal.

Pero, he aquí, que, la ganancia extraordinaria de la reunificación ha sido una consecuencia apenas perseguida intencionalmente por los propios alemanes; se ha producido como consecuencia inercial del desmoronamiento comunista: el régimen perdió su apoyo externo soviético y se quedó sin cabeza ni dirección. Las prevenciones y los prejuicios de los vecinos europeos para aceptar de nuevo una Alemania fuerte en el continente hubieran prolongado una relación artificial de dos Estados democráticos en Alemania si no hubiera sido por las preferencias diplomáticas de Norteamérica. La ciudadanía, prácticamente inexistente de la DDR, sólo empujo como reacción para sacudirse la presión externa de un poder que carecía no solo de legitimidad y apoyo voluntario sino de proyecto e iniciativa, y lo hizo acogiéndose a la corriente reformista abierta por Gorbachov y los demás países del Este eu- ropeo. Se expresó ante todo instintivamente en la calle, como movimiento de masas («somos el pueblo», «somos un pueblo»): no como organización social o política, en contraste con las transiciones políticas en las dictaduras anti-modernas de la Península Ibérica, por ejemplo. La única oposición política que tuvo éxito lo tuvo en alianza con las fuerzas reformistas del SED: los demás grupos de intelectuales, que solían todavía creer en la utopía socialista malograda por la dictadura comunista, no tenían comprensión ni canales de comunicación con el sentir popular. En una sociedad tan extremada y artificialmente politizada y atrapada en el Estado no había espacio vital para una orientación política alternativa y segura de sí misma. Esta desorientación y desgana democrática perdurará bastante tiempo aún, pues muy pronto se incrementó con el desengaño posterior a su inclusión en el capitalismo social del Oeste: el mercado internacional no acudió precisamente ofreciendo nuevas oportunidades. Ni siquiera para la actividad profesional cualificada mejoraron las condiciones, pues la habilidad técnica ni siquiera en las actividades científicas naturales es suficiente, no digamos ya en el campo de la creatividad cultural y humanista.

La globalización demandaba inglés y no ruso, capacidad de iniciativa y comunicación y no integración pasiva en un organigrama. Llama la atención que una sociedad desarrollada y con unos niveles educativos notables sufriera el espejismo de haber pertenecido a la élite modernizadora del Este, pero ignorante de los hábitos sociales del Oeste. Dos décadas después de la caída del Muro, llama la atención su relativa atonía intelectual, la secuela de una crónica inhibición social comunicativa. En Berlín las nuevas oportunidades derivadas de la nueva capitalidad política y la llegada de extranjeros del Este y del Oeste ocultan esta retracción, pero en el interior provincial, la despoblación y la caída de la natalidad la acentúan: a pesar de la renovación urbana, de infraestructuras e instituciones, realizada en gran medida con la ayuda inicial del Este. La entera comunidad política de la nueva nación-estado pierde una energía muy necesaria y prescinde de una experiencia histórica peculiar. Sería ingenuo pensar que después de veinte años de la caída del Muro, que siguió al final del comunismo soviético, el establecimiento de unas relaciones diplomáticas democráticas entre la Alemania unificada en la Unión Europea y la Rusia actual es un objetivo sencillo. Pero, sin duda alguna, esta tarea histórica se halla condicionada, desde el lado alemán, por la todavía pendiente reintegración activa de los Alemanes del Este como comunidad cívica. El efecto más negativo y perdurable de la división política de Alemania ha sido una larga interrupción del aprendizaje social cooperativo en la sociedad del Este, y el reconocimiento interpersonal es imprescindible para el desarrollo de la capacidad de autocontrol libre del ciudadano y de su responsabilidad social; sin empresa autónoma, sin vida pública civil, sin otra comunicación exterior relevante que no tuviera lugar a través de los partidos comunistas y los otros países socialistas. La reelaboración crítica del pasado comunista permite aprovechar una experiencia traumática para restablecer unas relaciones más justas y razonables en el interior de Alemania y para afirmar en nuevo papel de Alemania y de la cultura en lengua alemana en Europa y en el mundo, comenzando por una nueva relación con la Rusia postcomunista, una vez que ha caído el castillo de naipes de la federación soviética. 